\title{
ARTICLES
}

\section{PERRY V. SCHWARZENEGGER: TRYING SAME-SEX MARRIAGE}

\author{
MICHAEL J. RITTER ${ }^{\star}$
}

1. Introduction ................................. 363

II. Same-Sex Marriage in California $\ldots \ldots \ldots \ldots \ldots \ldots \ldots \ldots . .365$

III. The Parties to Perry........................... 370

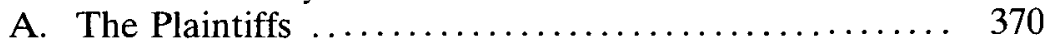

B. The Defendants ........................ 374

IV. The Perry Opinion \& the Order Denying a Stay ........ 377

A. The Due Process Clause Challenge.............. 377

B. The Equal Protection Clause Challenges .......... 380

C. The Trial Court's Denial of the Stay ............. 385

V. Perry's Possibilities ............................. 387

A. Standing $\ldots \ldots \ldots \ldots \ldots \ldots \ldots \ldots \ldots \ldots \ldots \ldots \ldots \ldots \ldots \ldots \ldots \ldots, 388$

B. The Merits $\ldots \ldots \ldots \ldots \ldots \ldots \ldots \ldots \ldots \ldots \ldots \ldots, 389$

\section{INTRODUCTION}

Commentators following Perry v. Schwarzenegger,${ }^{1}$ in which plaintiffs mounted federal constitutional attacks against the State of California's constitutional prohibition of same-sex marriage, have dubbed it "the highest-profile civil rights case of the decade."2 Indeed, Perry has-and will continue to have-palpable significance. Though Perry is not the

* Briefing Attorney to the Honorable Justice Rebecca Simmons, Fourth Court of Appeals of Texas; J.D., The University of Texas, 2010, with honors; B.A., Trinity University, 2007, cum laude. The author worked on Perry v. Schwarzenegger at the San Francisco City Attorney's Office during the summer of 2009.

1. 704 F. Supp. 2d 921 (N.D. Cal. 2010).

2. See, e.g., John Rogers, Ted Olson Supports Carly Fiorina's Senate Bid. Carly Fiorina Supports Prop 8. Huh!, QuEerTY.COM (Aug. 4, 2010), http://www.queerty.com/tedolson-supports-carly-fiorinas-senate-bid-carly-fiorina-supports-prop-8-huh-20100804. 
first federal constitutional challenge to the prohibition of same-sex marriage, it is the first instance of a federal trial court making findings of fact regarding same-sex marriage. ${ }^{3}$

After the trial judge, Chief Judge Vaughn Walker, issued the court's opinion favoring the plaintiffs and enjoining Proposition 8's enforcement ${ }^{4}$ the defendant-intervenors ${ }^{5}$ filed a Notice of Appeal and requested a stay of the court's order until the Ninth Circuit Court of Appeals addresses the merits. ${ }^{6}$ Judge Walker denied the defendant-intervenors' request for a stay because, among other things, the defendants were unlikely to succeed on the merits, as they lacked Article III standing to

3. See Maura Dolan, Prop. 8 Trial to Include Unprecedented Testimony, L.A. Times, Jan. 11, 2010, http://articles.latimes.com/2010/jan/11/local/la-me-prop8-trial11-2010jan11 ("'This is the first time that you will have this kind of record being made' on the social, religious and legal implications of same-sex marriage."). The trial court's fact finding was based on testimony from witnesses claiming a right to same-sex marriage and contending that Proposition 8 violated their constitutional guarantees. Id. The two same-sex couples that initially filed suit testified to their personal experience in pursuit of the right to marry. Id. Numerous experts also testified about the historical pattern "of discrimination against homosexuals and the history of marriage." Id.

4. Perry v. Schwarzenegger, 704 F. Supp. 2d 921, 1003 (N.D. Cal. 2010) (holding that the enforcement of Proposition 8 is unconstitutional). "The evidence shows conclusively that Proposition 8 enacts, without reason, a private moral view that same-sex couples are inferior to opposite-sex couples." Id. As the Supreme Court noted in Romer v. Evans, animus does not provide a rational basis for the government to withhold rights from a class of people. Id. (citing Romer v. Evans, 517 U.S. 620, 634 (1996)).

5. The defendants in Perry included California government officials ("official defendants") and a group of proponents that supported Proposition 8 and intervened in the case ("defendant-intervenors"). For a further discussion of the defendants in this case refer to Section B, Part III of this Article.

6. Notice of Appeal, Perry v. Schwarzenegger, 704 F. Supp. 2d 921 (N.D. Cal. 2010) (No. 09-CV-2292 VRW) (notifying all relevant parties of the defendants' intent to appeal the decision); Defendant-Intervenors' Motion for Stay Pending Appeal at 2-3, Perry v. Schwarzenegger, 704 F. Supp. 2d 921 (N.D. Cal. 2010) (noting that the defendants wanted the courts' decision to be suspended pending the ruling from the Ninth Circuit Court of Appeals). Defendants argued four main points in their motion. First, they argued that even if the court ruled in favor of the plaintiffs and stated that Proposition 8 violated the Constitution, the defendants would nevertheless win on appeal; thus it would be better to just suspend the judgment. Defendant-Intervenors' Motion for Stay Pending Appeal at 2-4, Perry v. Schwarzenegger, 704 F. Supp. $2 d 921$ (N.D. Cal. 2010). Second, they reasoned that allowing same-sex marriages before the appeal would create administrative problems in having to revoke any marriages that took place between the judgment and the appeal, and would also create unnecessary anxiety for the couples relying on the judgment. $I d$. Third, they noted that the plaintiffs had actually mentioned that they had chosen not to get married until they were certain the ruling would not be overturned and their marriage revoked. $I d$. at 6 . Finally, defendants pointed out that granting a stay of execution of the judgment would be best for Californians in that it would prevent uncertainty, while maintaining the sanctity of marriage in the way the citizens had been supporting it through their voting efforts in the past. Id. at 6-7. 
challenge the trial court's decision. ${ }^{7}$ The defendant-intervenors then appealed Judge Walker's judgment and order denying the stay to the Ninth Circuit, which is expected to release its decision on the stay in early $2011 .^{8}$ Regardless of the outcome at the Ninth Circuit, many expect the losing party to seek review by the Supreme Court of the United States ${ }^{9}$ because either party may file a writ of certiorari before or after a decision by the Ninth Circuit. ${ }^{10}$

This Article discusses the progression of Perry from the filing of the case to its current status before the Ninth Circuit. It also offers an indepth analysis of both the history of the case and the trial court's decision, hopefully serving as a springboard and reference for future scholarly discussions of this case's potential impact on sexual orientation's constitutional situation. Part II of this Article reviews the relatively recent legal history of same-sex marriage in California, tracing the events that ultimately culminated in Proposition 8 , which is the subject of Perry's controversy. Part III introduces the parties to Perry, explains the bases for their involvement in the case, and describes their constitutional arguments for and against Proposition 8. Part IV summarizes and explains the trial court's decision on the merits. Part V concludes this Article with a legal analysis of Perry's possible future.

\section{Same-Sex Marriage in California}

Since it gained statehood in 1849, the Constitution of the State of California conceptualized marriage as consisting of a husband and a wife. ${ }^{11}$

7. Order Denying Defendant-Intervenors' Motion to Stay Pending Appeal at 6, Perry v. Schwarzenegger, 704 F. Supp. $2 d 921$ (N.D. Cal. 2010), available at https://ecf.cand.uscourts.gov/cand/09cv2292/files/Final_stay_order.pdf (discussing when granting a stay is appropriate).

8. Jillian Jones, Prop. 8 Debate May Not Settle Until 2011, NApA Valdey ReG., Aug. 21, 2010, http://napavalleyregister.com/news/local/article_4518e8bc-adaa-11df-9e7c-001cc4 c002e $0 . h t m l$. Though usually the process would take much longer, the Ninth Circuit has scheduled oral arguments regarding Judge Walker's order for early December 2010, considerably expediting the process. Id. However, same-sex marriages in California will remain suspended until the Ninth Circuit issues its opinion on the trial court's order in denying the stay. $I d$. The stay would effectively reinstate Proposition 8 until the Ninth Circuit's decision is handed down in early 2011. Id.

9. David Cole, How Will Gay Marriage Fare in the Supreme Court?, N.Y. REv. OF Books Blog (Aug. 11, 2010, 10:10 AM), http://www.nybooks.com/blogs/nyrblog/2010/aug/ 11/how-will-gay-marriage-fare-supreme-court (speculating about the possible outcomes "[i]f and when" Perry v. Schwarzenegger is heard by the Supreme Court).

10. See 28 U.S.C. $\$ 1254(1)$ (2006) (explaining the requirements for an appeal to the Supreme Court of the United States).

11. Perry v. Schwarzenegger, 704 F. Supp. 2d 921, 957 (N.D. Cal. 2010) (providing historical references to California's interpretation of marriage). According to the California Supreme Court, the first session of the California legislature assumed marriage in- 
In 2000, California statutorily prohibited State recognition of same-sex marriages. ${ }^{12}$ The California Family Code defined-and continues to define-marriage as a contract between "a man" and "a woman." 13 Though county clerks throughout California consequently refused to issue marriage licenses to same-sex couples following the enactment of this statutory proscription, ${ }^{14}$ Gavin Newsom, the Mayor of the City and County of San Francisco, ${ }^{15}$ directed the San Francisco County Clerk to depart from the routine practices of other counties and issue marriage licenses to applicants without regard to sex or sexual orientation. ${ }^{16}$ Mayor Newsom supported his directive with decisions from other states' courts that held

volved persons of the opposite sex. In re Marriage Cases, 183 P.3d 384, 407 (Cal. 2008). "California's current marriage statutes derive in part from [its] Civil Code, enacted in 1872 ," which requires a man and a woman to be of a certain age before being able to consent to marriage. Id. at 408-09.

12. See Perry v. Schwarzenegger, 704 F. Supp. 2d 921, 927 (N.D. Cal. 2010) (describing the events that led to the passage of Proposition 8). California voters adopted the California Defense of Marriage Act, also known as Proposition 22, in November 2000. Id. Proposition 22 amended the California Family Code to require marriage be only between a man and a woman. CAL. FAM. CODE $\$ 308.5$ (Deering 2006), invalidated by Perry v. Schwarzenegger, 704 F. Supp. 2d 921 (N.D. Cal. 2010). The City of San Francisco and other parties filed actions in state court challenging Proposition 22 as violating the equal protection rights of same-sex couples. Perry v. Schwarzenegger, 704 F. Supp. 2d 921, 928 (N.D. Cal. 2010). In May 2008, Proposition 22 was overturned, allowing the issuance of marriage licenses to same-sex couples until the passage of Proposition 8. Id.

13. CAL. FAM. Code $\$ 300$ (a) (Deering Supp. 2009) ("Marriage is a personal relation arising out of a civil contract between a man and a woman, to which the consent of the parties capable of making that contract is necessary."). As of September 2010, thirty-nine states passed laws defining marriage as between a man and a woman, effectively banning same-sex marriage. See Same Sex Marriage, Civil Unions and Domestic Partnerships, Nat'L CONF. OF STATE Lisis., http://www.ncsl.org/default.aspx?tabid=16430 (last visited Oct. 19, 2010). On the other hand, five states and the District of Columbia have passed laws allowing the issuance of marriage licenses to same-sex couples: Massachusetts, Connecticut, Iowa, Vermont, and New Hampshire. Id. Additionally, three states-New York, Maryland, and Rhode Island-recognize same-sex marriages conducted in other states even though they themselves do not allow issuance of licenses to same-sex couples. Id.

14. See Cal. Fam. Code $\$ 300$ (a) (Deering Supp. 2009) (constructively prohibiting same-sex marriage); CAL. FAM. CODE $\$ 350$ (a) (Deering 2006) (explaining the role of county clerks in the marriage process). In California, county clerks are necessarily part of the process required to make a marriage legally binding because the parties "shall first obtain a marriage license from a county clerk" before entering into a marriage agreement. CAL. FAM. CODE $\$ 350$ (a) (Deering 2006).

15. This Article collectively refers to the City and County of San Francisco as "San Francisco."

16. Lockyer v. City \& Cnty. of S.F., 95 P.3d 459, 464 (Cal. 2004) (identifying the events that served as the basis for the litigation). The county clerk created gender-neutral documents to be used by same-sex couples in applying for, and obtaining a marriage license. Id. at 465 . These new forms also contained a proviso that warned applicants that their marriage might not be recognized by anyone other than San Francisco. Id. 
the denial of marriage rights to same-sex couples violated their constitutional guarantees of privacy, due process, and equal protection. ${ }^{17}$

Several opponents of same-sex marriage challenged San Francisco's practice of issuing marriage licenses to same-sex couples by requesting judicial stays of the practice. ${ }^{18}$ In Lockyer v. City \& County of San Francisco, ${ }^{19}$ the California Supreme Court held that San Francisco officials exceeded their authority by issuing marriage licenses in contravention of state statute. ${ }^{20}$ Then-Attorney General Bill Lockyer filed an original petition in the California Supreme Court, seeking to enjoin the city's practice. $^{21}$ The Court issued a stay, holding that Mayor Newsom's directivedespite its good faith basis-was premature in the absence of a judicial decree on the matter. ${ }^{22}$

Same-sex couples who subsequently applied for, but were denied marriage licenses filed challenges to California's limited definition of marriage, advancing substantially similar grounds as Mayor Newsom: that the prohibition violated the State constitution's privacy, due process, and equal protection guarantees. ${ }^{23}$ The California Supreme Court consoli-

17. Id. at 464-65 (explaining the legal theory of San Francisco's defense in reference to the equal protection clause of the California Constitution).

18. Id. at 465 (describing the attempts of opponents to same-sex marriage to stop the recording of same-sex marriages by the county clerk). Two individual actions were filed in an attempt to obtain an immediate stay of San Francisco granting marriage licenses to same-sex couples. Id. at 465-66. The San Francisco Superior Court declined to grant an immediate stay after conducting hearings for both of the actions. Id. at 466 . In these proceedings the City advanced a cross-complaint requesting a declaration from the court stating statutes that disallow the issuance of same-sex marriage licenses were unconstitutional. Id. at 466 n.6.

19. 95 P.3d 459 (Cal. 2004).

20. Lockyer, 95 P.3d at 463 (Cal. 2004). The court noted that the power to interpret and determine the constitutionality of a statute enacted by the legislature lies with the judiciary-not with an executive official. Id.

21. Id. at $464 \mathrm{n} .2$ (discussing Attorney General Lockyer's role in the events leading up to the Perry case).

22. Id. at 483, 499 (finding against San Francisco, and voiding all same-sex marriages issued by the county clerk prior to this decision).

23. Compare In re Marriage Cases, 183 P.3d 384, 404 (Cal. 2008), superseded by constitutional amendment CAL. CONST. art. $1 \S 7.5$ (describing the various challenges brought by same-sex couples and how they are mirrored after the Mayor of San Francisco's arguments), with Lockyer v. City \& Cnty. of San Francisco, 95 P.3d 459, 464-65 (Cal. 2004). Although the same-sex couples challenged the Constitution on the grounds of privacy, due process, and equal protection, the Superior Court only analyzed their challenge in terms of equal protection. In re Marriage Cases, 183 P.3d 384, 404 (Cal. 2008), superseded by constitutional amendment CAL. CoNsT. art. $1 \S 7.5$. The lower court applied strict scrutiny analysis to the equal protection claim, finding there was no legitimate state interest in outlawing same-sex marriages. Id. Upon review by the court of appeals, the decision of the lower court was reversed for various reasons, specifically with the lower courts' characterization 
dated these cases on appeal in In re Marriage Cases,${ }^{24}$ in which it struck down the State's statutory definition of marriage. ${ }^{25}$ The Court reasoned that legal classifications on the basis of sexual orientation do not pass muster under a strict scrutiny analysis, and, therefore, violate the State's constitutional guarantees of equal protection, privacy, and due process. ${ }^{26}$

Immediately following In re Marriage Cases, approximately eighteen thousand same-sex couples successfully obtained marriage licenses from counties throughout California. ${ }^{27}$ Opponents of same-sex marriage launched a ballot initiative measure to reverse the decision that permitted these marriages. ${ }^{28}$ The measure, known as Proposition 8 , proposed to engraft the following language into the constitution: "Only marriage between a man and a woman is valid or recognized in California."29 On November 4, 2008, California voters favoring Proposition 8-organized

of the fundamental right to marry and its standard of review under the equal protection clause. Id.

24. 183 P.3d 384 (Cal. 2008), superseded by constitutional amendment CAl.. Const: art. $1 \$ 7.5$.

25. Id. at 401 (holding California's current definition of marriage is not a compelling state interest). The court began its discussion with the current definition of marriage by exploring how marriage was characterized in statutes from the $1800 \mathrm{~s}$. Id. at 407-10. It acknowledged that "the statutory designation of marriage as a relationship between a man and woman has remained unchanged." $I d$. at 408 . The court discussed changes made in the 1960 s and 1970s, including the elimination of "male" and "female" references in the consent section that ultimately resulted in same-sex couples trying to apply for marriage certificates. Id. at 408-09. Legislation resulting from this confusion in the 1970 s provided a basis for the current definition of marriage, and the court acknowledged that the parties to the suit agreed that the current statutory language "limits marriages that lawfully may be performed in California to marriages of opposite-sex couples." Id. at 409.

26. Id. at 401,429 (determining the proper standard of review and holding the statute could not withstand the constitutionally required scrutiny). The petitioners argued strict scrutiny should be the standard of review applied to their equal protection challenge, reasoning they were a suspect class being subjected to discrimination on the basis of sex or gender. $I d$. at 401 . The court disagreed, but applied strict scrutiny analysis anyway, comparing it to gender, race, and religion. $I d$. The court reasoned that discrimination based on sexual orientation is "a constitutionally suspect basis upon which to impose differential treatment." Id. It further reasoned strict scrutiny analysis was necessary because the exclusion of same-sex couples from the institution of marriage infringed on their fundamental interest to enjoy the same family relationships as opposite-sex couples. Id.

27. See Perry v. Schwarzenegger, 704 F. Supp. 2d 921, 928 (N.D. Cal. 2010).

28. Id. (approval of Proposition 8 in November 2008 brought the issuance of marriage licenses for same-sex couples to a halt).

29. Id. at 927 (explaining arguments opponents of same-sex marriage have raised in support of Proposition 8). Proponents explain, "Proposition 8 is about preserving marriage; it's not an attack on the gay lifestyle." Id. at 930 (emphasis omitted). Although proponents of Proposition 8 agree that homosexuals have the right to their lifestyle in private, they strongly disagree with redefining the traditional definition of marriage for society. Id. 
primarily by the Yes On 8 Campaign and Perry's defendant-intervenorsdefeated the Proposition's opponents by a $52.3 \%$-to- $47.7 \%$ vote. ${ }^{30}$

Same-sex couples that were unable to procure marriage licenses postProposition 8 filed suit to challenge the amendment. ${ }^{31}$ The California Supreme Court consolidated three such cases and, in Strauss v. Horton, ${ }^{32}$ affirmed the validity of the amendment. ${ }^{33}$ The Strauss plaintiffs pled that Proposition 8, which carved out an exception to the guarantees of California's Constitution, was invalid because it constituted a revision that required a prior approval of two-thirds of the California Senate and Assembly. ${ }^{34}$ They also argued the State constitution's protection-of-minority function was judicial in nature, and could not be altered through the legislative process without violating the constitutional concept of separation of powers. ${ }^{35}$ The plaintiffs finally contended that Proposition $8 \mathrm{did}$ not retroactively nullify the same-sex marriages that occurred post-In re Marriage Cases and pre-Proposition $8 .^{36}$ Though the California Supreme Court held that Proposition 8 was neither an invalid revision of the Constitution nor a violation of the separation of powers doctrine, it protected the eighteen thousand couples from retroactive application of Proposition 8 because the text of the measure did not expressly apply to past same-sex marriages. ${ }^{37}$ The same day that the California Supreme Court announced its decision in Strauss, two same-sex couples filed suit in the

30. See 2008 Proposition 8 Map, Cal. Secretary of State Debra Brown, http:// www.sos.ca.gov/elections/sov/2008_general/maps/returns/props/prop-8.htm (last visited Oct. 21, 2010) (establishing that supporters of Proposition 8 edged out opponents by a $4.6 \%$ margin).

31. See Strauss v. Horton, 207 P.3d 48, 68 (Cal. 2009).

32. 207 P.3d 48 (Cal. 2009).

33. Id. at $63-64$.

34. Id. at $61,78-79$. An amendment may be proposed by either the legislature or by proposition of the voters, but a revision must be brought forth by either the legislature or a constitutional convention. Id. at 79-80.

35. Id. at 114 (explaining that separation of powers does not preclude the possibility of lawful cross-consideration of issues by more than one branch of government). The plaintiff's contention was based on the idea that the separation of powers doctrine establishes sharp lines that divides the government into three distinct entities. Id. at 114-15 (citing Superior Court v. Cnty. of Mendocino, 913 P.2d 1046, 1051 (Cal. 1996)). The California courts have consistently held that these lines are not iron-clad and that to deny the interrelationships of the different branches is unrealistic. Id. at 155 . As such, the lines may be crossed occasionally and one branch may permissibly reverse what another branch has done if that reversal is necessary to maintain a balance in the process. Id. at 115 .

36. Id. at 119 (addressing the effect of the language in Proposition 8 on marriages that occurred before its enactment). Without decisive language explicitly stating to the contrary, a newly enacted rule only applies prospectively, regardless of whether it was created through legislative action or the initiative process. Id.

37. Strauss, 207 P.3d at 59, 122. 
federal district court of the Northern District of California, arguing that Proposition 8 violated the U.S. Constitution. ${ }^{38}$

\section{The Parties to Perry}

\section{A. The Plaintiffs}

The Perry plaintiffs initially consisted of two same-sex couples. ${ }^{39}$ One couple, Kristin Perry and Sandra Stier, lives together in Berkeley, California, with their four children. ${ }^{40}$ Perry and Stier became partners in 2000. They initially received a marriage license from San Francisco in 2004 prior to Lockyer, which resulted in the stay and invalidated marriage licenses issued by the City. ${ }^{41}$ Given the legal uncertainty surrounding the recognition of same-sex marriage, the couple decided against getting married even after In re Marriage Cases to avoid further disappointment. ${ }^{42}$ After the passage of Proposition 8, a team of high-profile activists and attorneys-including Ted Olson and David Boies, former adversaries in the Supreme Court's 2000 decision, Bush v. Gore ${ }^{43}$-approached Perry and Stier, persuading them to become plaintiffs to challenge the amendment on federal constitutional grounds. ${ }^{44}$

The other couple, Paul Katami and Jeffrey Zarrillo, joined Perry and Stier in their challenge to Proposition 8. Katami and Zarrillo became

38. See generally Complaint for Declaratory, Injunctive, or Other Relief, Perry v. Schwarzenegger, 704 F. Supp. 2d 921 (N.D. Cal. 2009) (No. CV-09-02292 VRW), 2009 WL 1490740 (claiming unequal treatment based on sexual orientation violates the Equal Protection Clause under the Fourteenth Amendment).

39. Perry v. Schwarzenegger, 704 F. Supp. 2d 921, 927 (N.D. Cal. 2010) (noting that although the original plaintiffs in Perry only consisted of one same-sex couple, other samesex couples subsequently joined the suit).

40. Id. (discussing the background of the parties).

41. See Eve Conant, Accidental Activists, NıwsweEk, Jan. 11, 2010, http://www.newsweek.com/2010/01/10/accidental-activists.html (concluding that San Francisco's issuance of marriage licenses before being enjoined by Lockyer is legally void).

42. Id. (discussing the state of uncertainty surrounding same-sex couples and their desire to legally marry).

43. 531 U.S. 98, 103 (2000) (deciding whether Florida's procedures for resolving the 2000 Presidential election violated the U.S. Constitution). Ted Olson, a Republican, argued for George W. Bush in Bush v. Gore, while David Boies, a Democrat, represented Al Gore. Tony Castro, Proposition 8 Battle Heading to Federal Arena, DAlty News of Los Angeles, May 28, 2009, at A1, available at 2009 WLNR 16515614. The American Foundation for Legal Rights originally contacted Olson for the case, and Olson later brought on Boies to join him as co-counsel. Id.

44. Eve Conant, Accidental Activists, NEwsweis, Jan. 11, 2010, http:/www.newsweek.com/2010/01/10/accidental-activists.html (reflecting Perry's decision to take the necessary steps to file a lawsuit that would challenge Proposition 8). 
partners in $2001 .^{45}$ In 2009, their application for a marriage license was denied due to Proposition $8 .^{46}$ Unlike Perry and Stier, though, Katami and Zarrillo have delayed starting a family until their relationship was solidified through marriage. ${ }^{47}$

Finally, San Francisco and several gay and lesbian rights organizations moved to intervene in the case as plaintiffs in July 2009.48 San Francisco based its motion to intervene on the grounds that Proposition $8 \mathrm{com}$ pelled it to violate the rights of its citizens. ${ }^{49}$ In its motion to intervene, San Francisco opposed the intervention by several gay and lesbian rights organizations, arguing that intervention would result in unnecessary interference and delay. ${ }^{50}$ In August 2009, Chief Judge Walker granted the

45. Transcript of Proceedings Vol. 1 at 80, Perry v. Schwarzenegger, 704 F. Supp. 2d 921 (N.D. Cal. 2010) (No. 09-CV-02292 VRW) (detailing the direct-examination testimony of Jeffery Zarrillo).

46. Id. at 88 (recounting the effect Proposition 8 had on Katami and Zarillo's ability to be legally married as a same-sex couple in California). Katami testified that he felt being married would give more meaning to his relationship with Zarillo. Id. at 88-89.

47. Id. at 89 (citing the fact that Zarrillo and Katimi felt it necessary to wait to have children because of Proposition 8). Katami wanted to get married not only to show his dedication to the relationship, but also specifically so their children "won't have to say, "[mly dad and dad are domestic partners." Id.

48. Perry v. Schwarzenegger, 704 F. Supp. 2d 921, 927 (N.D. Cal. 2010) (naming parties seeking leave to intervene); see also Notice of Motion and Motion to Intervene as Party Plaintiff; Memorandum of Points and Authorities at 6, Perry v. Schwarzenegger, 704 F. Supp. 2d 921 (N.D. Cal. 2010) (No. 09-CV-2292 VRW), 2009 WL 1995823. San Francisco also petitioned the court to intervene as a party plaintiff claiming to have a substantial factual record. Press Release, City of San Francisco, San Francisco Moves to Intervene in Federal Challenge to Proposition 8 (July 23, 2009), available at http:/www.sfcityattorney. org/index.aspx?page $=170$. The City cited its work in the In re Marriage Cases that had provided "extensive evidence and proposed findings on strict scrutiny factors and factual rebuttals to long claimed justifications for marriage discrimination." Id.

49. Perry v. Schwarzenegger, 704 F. Supp. 2d 921, 928-29 (N.D. Cal. 2010) (intervening against enforcement of Proposition 8); see also Notice of Motion and Motion to Intervene as Party Plaintiff; Memorandum of Points and Authorities at 8, Perry v. Schwarzenegger, 704 F. Supp. 2d 921 (N.D. Cal. 2010) (No. 09-CV-2292), 2009 WL 2350844.

50. Carlos Santoscoy, Gay Groups Not Welcome in Federal Marriage Suit, ON ToP MAG., Aug. 8, 2009, http://www.ontopmag.com/article.aspx?id=4349\&MediaType=1\&Category $=26$ (reporting on an attempt made by gay rights organizations to intervene in Perry). The groups wishing to intervene, the National Center for Lesbian Rights, Lambda Legal, and the ACLU, are collectively known as Our Family Coalition. Id. The group funding the lead plaintiff in the Perry case, the American Foundation for Equal Rights, had serious qualms about letting the gay rights organizations intervene due to their reluctance to pursue previous litigation in federal courts, which the plaintiffs see as a sign that they will not zealously pursue this case if allowed to intervene. Id. According to Santoscoy, the reluctance to litigate on the part of Our Family Coalition was due to their belief that the current Supreme Court makeup is too conservative, and that a loss at that level would be harmful to their cause. Id. 
City's motion to intervene, but denied the motions of the gay and lesbian rights organizations. ${ }^{51}$

At trial, the plaintiffs argued that Proposition 8 violates both the Due Process Clause and the Equal Protection Clause of the Fourteenth Amendment to the U.S. Constitution. ${ }^{52}$ The plaintiffs asserted that Proposition 8 violates the Due Process Clause by limiting the choice of a consenting adult partner to marry, because the same-sex marriage ban substantially burdens the fundamental right of marriage. ${ }^{53}$ Further, modern Supreme Court precedent has always been characterized by the choice of who to marry. ${ }^{54}$ The plaintiffs proceeded to rebut six offered justifications for Proposition 8-procreation, responsible procreation, tradition, interstate recognition of California's marriages, administrative convenience, and moral disapproval-as failing to constitute compelling, or even legitimate, government interests..$^{55}$

51. Perry v. Schwarzenegger, 704 F. Supp. 2d 921, 928-29 (N.D. Cal. 2010) (detailing the procedural history of this action); see also Notice of Motion and Motion to Intervene as Party Plaintiff; Memorandum of Points and Authorities at 4, Perry v. Schwarzenegger, 704 F. Supp. 2d 921 (N.D. Cal. 2010) (No. 09-CV-02292 VRW), 2009 WL 1995823. Judge Walker denied the motions of the gay and lesbian rights organizations on the grounds that their interests were "indistinguishable from those advanced by the Plaintiffs." Chuleenan Svetvilas, Challenging Prop. 8: The Hidden Story, CAL. Law., Jan. 2010, http://www.cal lawyer.com/story.cfm?eid=906575\&evid $=1$.

52. Plaintiffs' and Plaintiff-Intervenor's Trial Memorandum at 1, Perry v. Schwarzenegger, 704 F. Supp. 2d 921 (N.D. Cal. 2010) (No. 09-cv-02292 VRW), 2009 WL 4718815 (listing the causes that will be presented at trial).

53. Id. at 4 .

54. Id. ("'Choices about marriage' are 'sheltered by the Fourteenth Amendment against the State's unwarranted usurpation, disregard, or disrespect."') (quoting M.L.B. v. S.L.J. ex rel. S.L.J., 519 U.S. 102, 116 (1996)).

55. Id. at 5-9. The plaintiffs and the plaintiff-intervenors contended the procreation argument fails because heterosexuals incapable of producing offspring are still permitted to marry. $I d$. at 6 . They argued that gay and lesbian marriage has no effect on procreation activities or marriage rates of heterosexuals. Id. Plaintiffs also argued there is no evidence to show a difference in the quality of the environment for children in either heterosexual or homosexual households. $I d$. at 7 . Further, the proponents' argument that the institution of marriage has remained constant over the years does not comport with history. Id. at 8 . Marriage has evolved with society to reflect current needs and values. Plaintiffs' and Plaintiff-Intervenor's Trial Memorandum at 8, Perry v. Schwarzenegger, 704 F. Supp. $2 \mathrm{~d} 921$ (N.D. Cal. 2010) (No. 09-CV-02292 VRW), 2009 WL 4718815. Forsaking fundamental rights merely because other states might not recognize them is hardly a credible argument. Id. Likewise, administrative convenience is no excuse for discrimination and according to the Supreme Court, does not constitute a legitimate state interest. Id. at 9; see Craig v. Boren, 429 U.S. 190, 198 (1976) (holding administrative convenience cannot survive intermediate scrutiny because administrative convenience is not an important governmental objective); see also Frontiero v. Richardson, 411 U.S. 677, 690-91 (1973) (finding administrative convenience cannot serve as a governmental interest under a strict scrutiny framework in relation to the Due Process Clause of the Fifth Amendment). 
The plaintiffs argued two separate violations of the Equal Protection Clause. ${ }^{56}$ First, Proposition 8 impermissibly discriminated on the basis of sexual orientation. ${ }^{57}$ This argument posited that the amendment denies gays and lesbians the opportunity to marry the person they love, but not heterosexual individuals. ${ }^{58}$ Gays and lesbians are a suspect or quasi-suspect class deserving of strict or at least heightened scrutiny under the Equal Protection Clause because there is a history of discrimination against homosexuals - a group that continues to remain relatively powerless. ${ }^{59}$ Further, sexual orientation is an immutable characteristic unrelated to one's ability to contribute to society. ${ }^{60}$ Alternatively, Proposition 8 fails even under the rational basis test and thus constituted a "bare . . . desire to harm a politically unpopular group[, which] cannot constitute a legitimate governmental interest."61

The plaintiffs' second Equal Protection Clause argument claimed that Proposition 8 impermissibly discriminates on the basis of sex, and, as

56. Plaintiffs' and Plaintiff-Intervenor's Trial Memorandum at 10-15, Perry v. Schwarzenegger, 704 F. Supp. 2d 921 (N.D. Cal. 2010) (No. 09-CV-02292 VRW), 2009 WL 4718815 (arguing Proposition 8 violates the Equal Protection Clause for more than one reason).

57. Id. at 11 (examining the implications of sexual orientation and how statutes classifying individuals based on sexual orientation should be scrutinized). Sexual orientation, the plaintiffs argued, falls under the right of privacy and deserves to be recognized as a fundamental right. Id. at 11-12; Lawrence v. Texas, 539 U.S. 558, 565 (2003). As Justice Kennedy stated in Lawrence, "Liberty presumes an autonomy of self that includes freedom of thought, belief, expression, and certain intimate conduct." Lawrence v. Texas, 539 U.S. 558,562 (2003). Plaintiffs also argued that sexual orientation does not relate to one's ability to contribute to society in a meaningful and positive way. Plaintiffs' and Plaintiff-Intervenor's Trial Memorandum at 12, Perry v. Schwarzenegger, 704 F. Supp. 2d 921 (N.D. Cal. 2010) (No. 09-CV-02292 VRW), 2009 WL 4718815.

58. Plaintiff' and Plaintiff-Intervenor's Trial Memorandum at 11, Perry v. Schwarzenegger, 704 F. Supp. 2d 921 (N.D. Cal. 2010) (No. 09-CV-2292 VRW), 2009 WL 4718815 (demonstrating the inequality of domestic partnerships compared to the institution of marriage). The right to marry is a fundamental interest and any statutory classification that significantly interferes with the fulfiliment of that right warrants an extensive evaluation of the state interests purported to be advanced by such classification. Zablocki v. Redhail, 434 U.S. 374, 388 (1978). Reasonable regulations that do not cause direct interference will not be subject to such exacting scrutiny. Id. at 386.

59. Plaintiffs' and Plaintiff-Intervenor's Trial Memorandum at 11, Perry v. Schwarzenegger, 704 F. Supp. 2d 921 (N.D. Cal. 2010) (No. 09-CV-2292 VRW), 2009 WL 4718815 (demonstrating the inequality of domestic partnerships compared to the institution of marriage).

60. Id. (arguing Proposition 8 must be held to a higher level of scrutiny than rational basis because the right to marry is a fundamental right).

61. Id. at 14 (citing Romer v. Evans, 517 U.S. 627, 634 (1996) (explaining animosity towards a group cannot form the basis of a legitimate public policy)). 
such, must substantially relate to an important governmental objective. ${ }^{62}$ This contention asserted that Proposition 8 constitutes a sex-based classification because it denies a woman the right to marry a person that the law permits a man to marry. ${ }^{63}$

\section{B. The Defendants}

The original defendants to the suit included an array of state officials, such as Governor Arnold Schwarzenegger, Attorney General Edmund Brown, and several county clerks. ${ }^{64}$ After Attorney General Brown refused to defend Proposition 8, conceding its unconstitutionality and the remaining state officials' failure to take a position on the merits of the case, ${ }^{65}$ the proponents of Proposition 8 that were responsible for putting the measure on the ballot and galvanizing its support moved to intervene as defendants in the suit. ${ }^{66}$ Chief Judge Walker granted leave to intervene in July 2009.67 Proposition 8's proponents founded and facilitated the Yes on 8 Campaign through its organization, ProtectMarriage.com. ${ }^{68}$

62. Id. at 14-15 (asserting that the court must employ at least intermediate scrutiny when analyzing Proposition 8). The State had the burden to prove that a sex-based classification is "substantially related" to an "important government purpose." Id. at 15.

63. Id.

64. Perry v. Schwarzenegger, 704 F. Supp. 2d 921, 928 (N.D. Cal. 2010).

65. Id. at 928-29 (discussing the procedural history of the case).

66. Id. at 930 (demonstrating the proponent's eventual failure to establish the government's interest in maintaining the traditional marriage in the district court). Two groups, the official proponents of Proposition 8 led by Dennis Hillingsworth and a rival group, the Campaign for California Families, sought to intervene as defendants. Notice of Motion and Motion for Intervention by Campaign for California Families at 1, Perry v. Schwarzenegger, 704 F. Supp. 2d 921 (N.D. Cal. 2010) (No. 09-CV-02292 VRW), 2009 WL 6594262; Perry v. Schwarzenegger, 704 F. Supp. 2d 921, 928-29 (N.D. Cal. 2010); see Answer of Proposed Intervenors at 1, Perry v. Schwarzenegger, 704 F. Supp. 2d 921 (N.D. Cal. 2010) (No. 09-CV-02292 VRW) 2009 WL 1562716. The court allowed the official proponents to intervene, but denied the Campaign for California Families' request. Perry $v$. Schwarzenegger, 704 F. Supp. 2d 921, 928 (N.D. Cal. 2010). The Campaign for California Families appealed. Perry v. Proposition 8 Official Proponents, 587 F.3d 947, 949 (9th Cir. 2010). The appellate court affirmed the district court's ruling stating that each party shared the "ultimate objective" and therefore, had adequate representation. Perry v. Proposition 8 Official Proponents, 587 F.3d 947, 949 (9th Cir. 2009). While the Attorney General conceded that Proposition 8 is unconstitutional, Governor Schwarzenegger remained more neutral, but supported the lawsuit because the Proposition 8 conflict asks "important constitutional questions that require and warrant judicial determination." Maura Dolan, Gov. Won't Defend Proposition 8, L.A. Times (June 18, 2009), available at 2009 WL 11613112.

67. Perry v. Schwarzenegger, 704 F. Supp. 2d 921, 930 (N.D. Cal. 2010) (stating that the proponents were granted leave to defend Proposition 8 in early July of 2009).

68. Id. at 930, 954 (explaining that the original supporters of Proposition 8 came together again to defend Proposition 8). As noted previously, it is presumed the proponents sought to intervene because of the lack of interest on the part of officials in the State of California. Id. at 928 . 
Notable members of the organization include the "Church of Jesus Christ of Latter-Day Saints ... the California Catholic Conference and a large number of evangelical churches."69

The Perry defendant-intervenors responded to the plaintiffs' Due Process and Equal Protection arguments in turn. ${ }^{70}$ They argued that Proposition 8 was not subject to strict scrutiny under the Due Process Clause because it imposed no burden on the fundamental right to marry. ${ }^{71}$ The defendant-intervenors offered the following reasons: first, there is no fundamental right to same-sex marriage because marriage has historically been defined as a union between two people of the opposite sex. ${ }^{72} \mathrm{Sec}$ ond, the definitional expansion of marriage to include interracial marriage and permit no-fault divorce did not fundamentally alter the institution of marriage the way permitting same-sex marriage would. ${ }^{73}$ And third, the Supreme Court's decision in Lawrence v. Texas ${ }^{74}$ recognized the constitutional right only to sexual behavior in the home. ${ }^{75}$

69. Id. at 930,955 (describing the influential role that members of Protect Marriage played in passing Proposition 8 into law).

70. Defendant-Intervenors' Trial Memorandum at 1-2, Perry v. Schwarzenegger, 704 F. Supp. 2d 921 (N.D. Cal. 2010) (No. 09-CV-2292 VRW) (claiming that neither due process rights nor guarantees of equal protection under the law justify the court in striking down Proposition 8 in spite of the result of California's public referendum). Current Supreme Court precedent declares that the traditional male-female concept of marriage does not conflict with personal rights afforded by the Fourteenth Amendment. Id. Therefore, since no fundamental right is being violated, under this view, the proper level of scrutiny by the court should be rational-basis review. Id.

71. Id. at 2 (arguing that the traditional definition of marriage as acknowledged by the people of the state of California in Proposition 8 violates no protected fundamental right under the U.S. Constitution and thus does not merit strict-scrutiny review).

72. Id. at 2-3. The overwhelming popular consensus, the defendant-intervenors argued, acknowledges that concepts of marriage have always been limited to men and women and generally envision procreation as its purpose. Id. Further, the Supreme Court has never contemplated a definition of marriage that includes a same-sex union. Id.

73. Id. at 3 (cautioning the court from inferring that same-sex marriage is somehow analogous to or made lawful by the acceptance of no-fault divorce or interracial marriage). To support their argument, the defendant-intervenors pointed to precedent concerning miscegenation, coverture, and no-fault divorce and the fact they all shared the common theme that marriage was defined between a man and a woman. Id. at 3-4. As such, the defendant-intervenors argue, their impact on the law did not logically broaden the definition of marriage to include homosexual unions. Id.

74. 539 U.S. 558 (2003) (holding that a Texas statute making "deviate sexual intercourse" illegal between persons of the same sex violated the Fourteenth Amendment's Due Process Clause).

75. Defendant-Intervenors' Trial Memorandum at 2, Perry v. Schwarzenegger, $704 \mathrm{~F}$. Supp. 2d 921 (N.D. Cal. 2010) (No. 09-CV-2292 VRW) (noting defendant-intervenors' argument that the U.S. Supreme Court has thus far denied that same-sex marriage is a fundamental right). 
Regarding the Equal Protection Clause challenges, the defendant-intervenors countered that Proposition 8 was subject only to rational basis review because it discriminates on the basis of sexual orientation, and based on Ninth Circuit precedent in High Tech Gays v. Defense Industry Security Clearance Office ${ }^{76}$ sexual orientation is not a suspect or quasisuspect class. ${ }^{77}$ They argued sexual orientation was not immutable, but rather "a complex and amorphous phenomenon that defies consistent and uniform definition." 78 The defendants also refuted the claims of prior discrimination against and the relative political powerlessness of gays and lesbians. ${ }^{79}$ They also responded that same-sex couples do not contribute to society in the same way that opposite sex couples do, because the latter has procreative capacities where the former does not. ${ }^{80}$ The defendants concluded this point by claiming that no court has ever held that a prohibition of same-sex marriage constituted sex discrimination. ${ }^{81}$ After arguing for the application of the rational basis test, the defendants offered a laundry list of forty-seven interests to which Proposition 8 was rationally related. ${ }^{82}$

76. 895 F.2d 563, 571 (9th Cir. 1990) (explaining why the court applied a rational basis standard of review).

77. See Defendant-Intervenors' Trial Memorandum at 4, Perry v. Schwarzenegger, 704 F. Supp. 2d 921 (N.D. Cal. 2010) (No. 09-CV-2292 VRW), 2009 WL 4718817 (urging the court to adopt a rational basis review of Proposition 8).

78. Id. at 5 (arguing for the proposition that sexual orientation is a choice rather than an inherent personal trait).

79. See id. at 5-6 (claiming gays and lesbians are more accepted than ever before in society and that, short of gay marriage, every proposed policy supporting homosexuals in California has become law).

80. Id. at 6 (arguing that because homosexual couples lack the procreative capacity they argue marriage is designed for, Proposition 8 should be reviewed under the rational basis test). However, contrary to proponents' assertion, procreative capacity has never been a condition for granting couples the right to marry. Perry v. Schwarzenegger, $704 \mathrm{~F}$. Supp. 2d 921, 992 (N.D. Cal. 2010). Marriage is not just about the right of individuals to engage in sexual intercourse, and such an assertion demeans the relationship between married couples. Id. (quoting Lawrence v. Texas, 539 U.S. 558, 567 (2003) (holding that homosexuals have the right to engage in private, consensual sexual activity))

81. Defendant-Intervenors' Trial Memorandum at 6, Perry v. Schwarzenegger, $704 \mathrm{~F}$. Supp. 2d 921 (N.D. Cal. 2010) (No. 09-CV-2292 VRW), 2009 WL 4718817 (arguing that because marriage is defined as a union between a man and a woman, excluding homosexuals from marriage is not discrimination based on sex).

82. See id. at 7-11 (arguing that recognition of same-sex marriages would undermine various governmental interests). 


\section{The Perry Opinion \& the Order Denying a Stay}

On August 4, 2010, Chief Judge Walker issued the trial court's opinion in favor of the plaintiffs. ${ }^{83}$ His order enjoined the official defendants, and all under their control, from enforcing Proposition $8 .^{84}$ The decision agreed with all substantive arguments presented by the plaintiffs, including that Proposition 8 violated the Due Process Clause and Equal Protection Clause of the Fourteenth Amendment. ${ }^{85}$

\section{A. The Due Process Clause Challenge}

Regarding the Due Process challenge, the Perry court acknowledged that the Due Process Clause protects liberty interests, including the fundamental right to marry. ${ }^{86}$ For the trial court, the Due Process issue turned on whether Proposition 8 impermissibly burdened the previously recognized fundamental right to marry or whether finding a Due Process violation would require the recognition of a new right. ${ }^{87}$ The court concluded that the plaintiffs did not seek to establish a new right, but correctly asserted that Proposition 8 violated the right to marry as understood by prior federal precedent. ${ }^{88}$ According to the court, the fundamental right to marry has always consisted of the freedom of two equal individuals who consensually choose to seek state recognition of their re-

83. Perry v. Schwarzenegger, 704 F. Supp. 2d 921, 926, 994-95, 997 (N.D. Cal. 2010) (holding Proposition 8 violated same-sex couples' rights under the Due Process and Equal Protection Clauses of the Fourteenth Amendment).

84. Id. at 1004 (explaining the remedial effects of the court's decision).

85. Id. at 993-95 (holding Proposition 8 excludes homosexuals from the institution of marriage without rational justification and domestic partnerships are an inferior substitution for marriage).

86. Id. at 991-92 (citing Turner v. Safely, 482 U.S. 78, 95 (1987) (recognizing marriage as a fundamental right, and as an "expression [ ] of emotional support and public commitment"); Zablocki v. Redhail, 434 U.S. 374, 388, 390-91 (1978) (overturning a statute requiring counseling prior to marriage for individuals with prior support obligations because it "unnecessarily interfered with the right to marry"); Cleveland Bd. of Educ. v. LaFleur, 414 U.S. 632, 639-40 (1974) (reiterating the idea of marriage and family life as a liberty afforded protection under the Due Process Clause of the Fourteenth Amendment); Loving v. Virginia, 388 U.S. 1, 12 (1967) (establishing the freedom to marry as one of the "vital personal rights essential to the orderly pursuit of happiness by free men"); Griswold v. Connecticut, 381 U.S. 479, 486 (1965) (protecting the right of married individuals to use contraceptives, referring to marriage as encompassing "a right of privacy older that the Bill of Rights-older than our political parties, older than our school system").

87. Perry v. Schwarzenegger, 704 F. Supp. 2d 921, 992 (N.D. Cal. 2010) (setting out the requirements for Due Process Clause analysis to determine if a right is fundamental).

88. Id. at 993 (distinguishing between the right plaintiffs seek, the right to marriage, from what the plaintiffs do not seek-a new right to same-sex marriage). 
lationship as a civil and secular, rather than religious, "union of equals." The state's interest in recognizing and regulating marriage was to promote "stable households, which in turn form the basis of a stable, governable populace." 90

The trial court noted that absent from the essential characteristics of the fundamental right to marry is any favor for procreation, the racial composition of the couple, and the gender composition of the couple. ${ }^{91}$ Procreation had never defined the fundamental right to marry, as the process of issuing of marriage licenses has never "inquired into [the couple's] procreative capacity or intent."92 Rather, under the Supreme Court's decision in Griswold $v$. Connecticut, procreation was a private choice of a couple, regardless of a couple's marital status. ${ }^{93}$ Furthermore, as the Supreme Court noted in Lawrence $v$. Texas, the fundamental right to marry encompasses much more than the mere right to have sexual relations. ${ }^{94}$

A preference for particular racial composition of two individuals who marry is as irrelevant to the fundamental right to marry as procreation, according to the trial court. ${ }^{95}$ Though racial restrictions on marriage were common prior to the mid-1950s, the Supreme Court's invalidation of these restrictions did not alter the definition of marriage or expand the fundamental right to marry. ${ }^{96}$ Instead, because the fundamental right to

89. Id. (outlining the changes in social perspective regarding marriage throughout history).

90. Id. at 992 (clarifying that a "procreative capacity or intent" is unnecessary for either a marriage or to ensure the state's interest).

91. Id. (explaining that while interracial marriage statutes have been struck down, among others, the institution of marriage has remained unchanged in the sense of being a union between two consenting adults that want to be recognized for their commitment to each other). The consistently recurring characteristics are: (1) two parties, (2) freely consenting, (3) to the formation of a relationship, (4) which entails supporting each other and each other's dependents. Id.

92. Perry v. Schwarzenegger, 704 F. Supp. 2d 921, 992 (N.D. Cal. 2010) (disavowing the mistaken belief that a marriage license is merely a license to procreate).

93. Id. (citing Griswold v. Connecticut, 381 U.S. 479, 485-86 (1965)) (recognizing choice and privacy are separate issues from procreative ability under Griswold).

94. Id. (citing Lawrence v. Texas, 539 U.S. 558, 567 (2003)).

95. See id. at 931-32 (drawing a comparison between interracial marriage before Lov. ing $v$. Virginia, and the alleged government interest asserted by defendants in Perry that procreation, or at least the ability to procreate, is necessary to a marriage and to society at large).

96. Id. at 992 (providing an example where eliminating prejudicial marriage restrictions does not necessarily alter what it means to be married). 
marry concerned the choice of two consenting adults, racial restrictions on marriage were impermissible burdens on the right to marry. ${ }^{97}$

The Perry court then explained that gender no longer plays an essential role in the fundamental right to marry. ${ }^{98}$ California's doctrine of coverture, which once required that a woman become the property of her husband upon marriage, is now abolished and is legally irrelevant to marriage, since the State recognized legal parity between the sexes. ${ }^{99}$ Like the notion of preferred racial composition of a married couple before it, the notion of a preferred gender composition is merely a historical shaping of marriage, rather than an essential characteristic of the fundamental right to marry under the Due Process Clause. ${ }^{100}$ After concluding that Proposition 8 burdened the fundamental right to marry, the trial court determined that Proposition 8 lacked a compelling, or even a legitimate, governmental justification. ${ }^{101}$

The trial court further determined that California's option for domestic partnerships failed to satisfy due process requirements, offering two rea-

97. Perry v. Schwarzenegger, 704 F. Supp. 2d 921, $992-93$ (N.D. Cal. 2010) (explaining why the Court struck down the statute at issue in Loving $v$. Virginia).

98. Id. (discussing gender in terms of how it is historically related to marriage). Attorney Katherine K. Baker argues that advocates for same-sex marriage experience problems in court because courts have failed to provide a proper definition of the institution of marriage. Katherine K. Baker, The Stories of Marriage, 12 J.L. \& FAm. STud. 1, 1-2 (2010). Even though the law does not touch gender roles within marriage, the fact that same-sex couples are not allowed to marry results in a gendered institution. Id. at 28 . By only allowing opposite-sex couples to marry, a state "reifies" gender, which is a result of the importance society places on "the expressive and constitutive benefits of marriage." Id. Baker suggests, "that which makes marriage a fundamental right may, in and of itself, create a gender equality problem." Id.

99. Perry v. Schwarzenegger, 704 F. Supp. 2d 921, $992-93$ (N.D. Cal. 2010) (discussing historical changes in the law that affected gender roles within the marriage). The doctrine of coverture originated in England and was brought to the American colonies. Claudia Zaher, When a Woman's Marital Status Determined Her Legal Status: A Research Guide on the Common Law Doctrine of Coverture, 94 Law Lisr. J. 459, 459 (2002). Coverture left the wife with no legal existence; for example, once married, everything she owned or acquired came under the control of her husband. Id. at 460-61. After the Industrial Revolution, society began to recognize wealth as a more important social value, which resulted in weakening the doctrine through the passage of Married Women's Property Acts. Id. at 461-62. Law librarian Claudia Zaher argues that some of the stigma of coverture continues to affect women today, particularly in regard to gender equality. Id. at 462.

100. Perry v. Schwarzenegger, 704 F. Supp. 2d 921, 992-93 (N.D. Cal. 2010) (comparing the stigma of same-sex marriage to the prejudice historically directed at interracial couples).

101. Id. at 995. "[F]undamental rights may not be submitted to [a] vote; they depend on the outcome of no elections." Id. (quoting W. Va. State Bd. of Educ. v. Barnette, 319 U.S. 624, 638 (1943)). The trial court referred to its discussion of state interests in its equal protection clauses analysis. See subpart IV, subsection B of this Article. 
sons in support. ${ }^{102}$ First was the "symbolic disparity" between marriage and domestic partnerships. ${ }^{103}$ Plaintiff-couple Zarrillo and Katami testified that "marriage has a 'special meaning' that would alter their relationships with family and others." 104 Based on the testimony of the plaintiffs, the court found that marriage holds a "culturally superior status" to domestic partnership. ${ }^{105}$ Second, because California's domestic partnership option provided the exact same rights to same-sex couples as marriage did to opposite-sex couples, the only justification for the creation of the parallel institution was to withhold the social benefits of marriage from same-sex couples. ${ }^{106}$

\section{B. The Equal Protection Clause Challenges}

The trial court agreed with the plaintiffs on all of their Equal Protection contentions: that Proposition 8 discriminates on the basis of sexual orientation; that sexual orientation is a suspect class deserving of strict scrutiny; Proposition 8 also discriminates on the basis of sex, and should be subject to heightened scrutiny; and that Proposition 8 fails to survive even a rational basis review. ${ }^{107}$

The court disagreed with the defendant-intervenors' position that Proposition 8 did not discriminate because it was not facially targeted at homosexuals because it did not reference homosexuality. ${ }^{108}$ It stated that Proposition 8 discriminated on the basis of sexual orientation because prohibitions on same-sex marriage prevented homosexual and bisexual

102. Id. at 994 (comparing domestic partnerships to marriage).

103. Id. at 994,996 (noting that proponents of Proposition 8 do not dispute that a domestic partnership is inferior, symbolically speaking, to marriage).

104. Id. at 932 (explaining that many day-to-day activities are made more awkward or difficult for Zarrillo and Katami because they cannot simply state that they are married). Zarrillo and Katami brought up an instance where they attempted to open a joint bank account, but they had to set it up as either a business account or a partnership because they were not married. Id. at 932-33. Perry and Stier, the other plaintiff couple, stated that being able to marry would "make them feel included 'in the social fabric." $I d$. at 933 .

105. Perry v. Schwarzenegger, 704 F. Supp. 2d 921, 994 (N.D. Cal. 2010) (affirming the contention that California disadvantages the plaintiffs by only allowing them to enter into domestic partnerships and not marriage). The court determined that California could not fulfill its due process obligation to permit people to marry when its alternative is an inferior institution designed to prohibit marriage for gay couples. Id.

106. Id. at 994 (contrasting California's designations of "marriage" and "domestic partnership").

107. Id. at 995-98 (agreeing with the arguments presented by plaintiffs in favor of same-sex marriage).

108. Id. at 996 (criticizing the proponents' attempts to mask the discriminatory intent of Proposition 8 since the only parties affected by the law were homosexuals). 
couples from marrying the consenting person of their choice, whereas heterosexual couples could marry. ${ }^{109}$

After noting that some discrimination on the basis of sexual orientation may also constitute discrimination on the basis of sex, the court held that Proposition 8 was an example of such discrimination. ${ }^{110}$ It reasoned that a woman in California could not marry a consenting person of her choice if that person was also a woman, but, if she were a man, California law would recognize the marriage. ${ }^{11}$ As such, the court determined that Proposition 8 must pass the heightened scrutiny required for laws making sex-based classifications. ${ }^{112}$

The trial court went even further in concluding that discrimination on the basis of sexual orientation should be subject to strict scrutiny review under the Equal Protection Clause. ${ }^{113}$ The rationale turned on the historical unequal treatment of gays and lesbians and the ability of homosexual individuals to live in society free of "impairment in judgment or general social or vocational capabilities" merely due to their homosexuality. ${ }^{114}$

Though the court viewed strict scrutiny as the proper standard of review, it conducted a justification-by-justification analysis, ultimately concluding that none of the defendant-intervenors' groups of purported justifications for Proposition 8 was rationally related to legitimate governmental interests. ${ }^{115}$ The court rejected the first group of purported rationales, which concerned preserving the traditional functions of marriage. ${ }^{116}$ It based its rejection on a Supreme Court holding that tradition alone constitutes no legitimate governmental interest for a discrimi-

109. Id. at 994 (discussing the differences between and the interrelation of sex discrimination versus discrimination based on sexual orientation); see also Massachusetts $\mathrm{v}$. U.S. Dept. of Health and Human Servs., 698 F. Supp. 2d 234, 248, 253 (D. Mass. 2010) (rejecting the Defense of Marriage Act (DOMA) of 1996 as unconstitutional). The DOMA was signed into law by President Clinton in 1996 and $\$ 3$ explicitly provides "the word 'marriage' means only a legal union between one man and one woman as husband and wife, and the word 'spouse' refers only to a person of the opposite sex who is a husband or a wife." Id. at 236.

110. Perry v. Schwarzenegger, 704 F. Supp. 2d 921, 996 (N.D. Cal. 2010) (equating discrimination against same-sex couples to discrimination based on gender).

111. Id.

112. Id. (determining the applicable standard of review based on its view of same-sex marriage as a gender discrimination issue).

113. Id. at 997 (recommending strict scrutiny for gender-based equal protection challenges, including for Proposition 8).

114. Id. at 967 (relating that the proponents of Proposition 8 could only point to one difference between same-sex and heterosexual couples).

115. See Perry v. Schwarzenegger, 704 F. Supp. 2d 921, 997-1004 (N.D. Cal. 2010).

116. Id. at 998 (asserting that tradition alone is not rationally related to a legitimate state interest). 
natory classification. ${ }^{117}$ Moreover, the court noted that marriage in California had abandoned traditionally required gender roles for a man and a woman in a marriage. 118 According to the court, "Proposition 8 thus enshrines in the California Constitution a gender restriction that the evidence shows to be nothing more than an artifact of a foregone notion that men and women fulfill different roles in civic life."119

The court similarly rejected the second group of purported interests, which proposed justifications concerning "proceeding with caution when implementing social changes."120 It found that, based on the plaintiffs' evidence at trial, permitting same-sex marriage would not affect the marriage rights of opposite-sex couples. ${ }^{121}$ It also determined that the defendant-intervenors' evidence lacked credibility on the issue, as California had previously recognized approximately eighteen thousand same-sex marriages. ${ }^{122}$

The defendant-intervenors' third group of justifications-all relating to the preference given to opposite sex couples with regards to child rearing-equally failed to satisfy the court. ${ }^{123}$ Five findings of facts dissuaded the court from accepting these justifications. First, the court found that same-sex parents and opposite-sex parents were equally qualified to raise children. ${ }^{124}$ Second, it found that Proposition 8 in no way encouraged opposite-sex couples to have more biological children. ${ }^{125}$ Third, Proposition 8 did not relate to raising children, as same-sex couples may raise

117. Id. (citing Heller v. Doe, 509 U.S. 312, 326 (1993)); Williams v. Illinois, 399 U.S. $235,239-40$ (1970) (rejecting the idea that what is traditional should always be preserved).

118. Perry v. Schwarzenegger, 704 F. Supp. 2d 921, 998 (N.D. Cal. 2010) (noting the tradition of limiting a citizen's choice of spouse arose at a time when spouses were legallymandated to follow gender-defined roles).

119. Id. (stating that California's constitutional amendment codifies antiquated notions of gender).

120. Id. (dispelling proponents' argument that same-sex marriage would cause vast and sweeping social change).

121. Id. at 998-99 (noting defendants' argument that allowing same-sex couples to marry would result in negative consequences for society as well as the institution of marriage).

122. Id. at 999-1003 (referring to the court's view that the evidence provided in support of Proposition 8 was weak in proving detrimental societal repercussions for granting same-sex couples the right to marry).

123. Perry v. Schwarzenegger, 704 F. Supp. 2d 921, 900-1000 (N.D. Cal. 2010) (recognizing plaintiffs' argument that a child's stability and growth would be adversely effected by same-sex parents did not persuade the court).

124. Id. at 999 (highlighting the relevant findings of fact that served as the basis for the court's ruling against Proposition 8, including Chief Judge Vaughn Walker's belief that gender did not affect parenting ability).

125. Id. at $999-1000$. 
and adopt children in California. ${ }^{126}$ Fourth, by refusing to recognize same-sex marriages, Proposition 8 necessarily required an increase of extramarital sex. ${ }^{127}$ And finally, the defendant-intervenors' evidence failed to convince the court that Proposition 8 reduced any household instability caused by the members of the couple being of the same-sex. ${ }^{128}$

The fourth group of purported justifications also failed. These purported interests attempted to justify Proposition 8 on the grounds that it protected the rights of same-sex marriage opponents under the First Amendment, and their rights to provide moral education for their children. ${ }^{129}$ The court rejected these interests, pointing out that California law prohibits discrimination with regard to public accommodations for same-sex domestic partnerships and marriage. ${ }^{130}$ It also held that, as a matter of law, Proposition 8 does nothing to take away the rights of married couples to oppose same-sex marriage or to teach their children to oppose same-sex marriage. ${ }^{131}$

Fifth, the court held that Proposition 8 cannot be supported by any justifications of keeping different classifications of relationships distinct. ${ }^{132}$ After hearing the evidence presented at trial, the court found moral and religious views to form the only basis for distinguishing between the different classes of couples. ${ }^{133}$ As a matter of law, the court overruled the defendant-intervenors' contention that Proposition 8 "advances administrative convenience," as the Supreme Court has rejected this as a legitimate government interest under the rational basis test. ${ }^{134}$ And to the extent that California had an interest in easing administrative burdens, the court questioned the burden of recognizing relationships

126. Id. at 1000 .

127. Id.

128. Perry v. Schwarzenegger, 704 F. Supp. 2d 921, 1000 (N.D. Cal. 2010) (referring to testimony by David Blankenhorn, defendants' expert witness "on marriage, fatherhood and family structure"). The Court pointed to Blankenhorn's dismissal of a study regarding same-sex marriage, even though he had never seen it before the trial, as evidence that his views were unreliable. Id at 949 . The study by Laura Langbein and Mark A. Yost, Jr. found same-sex marriage laws "have no adverse effect on marriage, divorce, and abortion rates, the percent of children born out of wedlock, or the percent of households with children under 18 headed by women." $I d$.

129. Id. at 1000-01 (citing the court's skepticism of Blankenhorn's testimony by saying he was defensive, failed to answer questions directly on cross-examination and presented conflicting testimony and expert opinions).

130. $I d$.

131. Id. (disapproving the theory that allowing same-sex marriage would result in the infringement of proponents' First Amendment rights).

132. Id. at 1001 .

133. Perry v. Schwarzenegger, 704 F. Supp. 2d 921, 936 (N.D. Cal. 2010).

134. Id. at 1001 (citing Craig v. Boren, 429 U.S. 190, 198 (1976)). 
through two separate institutions that provide identical benefits and are almost identical in character. ${ }^{135}$

Sixth, and finally, the court denied the defendant-intervenors' catchall interest, which offered "[a]ny other conceivable legitimate interests identified by the parties, amici, or the court at any stage of the proceedings."136 It classified many of the remaining interests as resting on "nothing more than a fear or unarticulated dislike of same-sex couples," which the court proceeded to explain was insufficient under rational basis scrutiny. ${ }^{137}$ This private moral view that same-sex couples are inferior to opposite-sex couples, the court explained, constitutes impermissible "animus towards gays and lesbians" rather than a legitimate government interest. $^{138}$ At this juncture, the court found that the Yes on 8 Campaign's efforts

[R]elied heavily on negative stereotypes about gays and lesbians and focused on protecting children from inchoate threats vaguely associated with gays and lesbians. . . . The evidence show $[$ ed] . . . that Proposition 8 played on a fear that exposure to homosexuality would turn children into homosexuals and that parents should dread having children who are not heterosexual. ${ }^{139}$

Because moral disapproval, in the absence of any valid state interest, failed to justify the passage of Proposition 8 , the court concluded that Proposition 8 did not meet the basic requirements of the rational basis test and thus violated both the Due Process Clause and the Equal Protection Clause. ${ }^{140}$

135. Id. (addressing defendants' argument that Proposition 8 is justified by administrative convenience).

136. Id. (rejecting the defendants' final proposed governmental interest in proposing and defending Proposition 8).

137. Id. at 1002 (emphasizing that when Chief Judge Vaughn Walker discounted the justifications advanced by Proposition 8 proponents, all that remained was the likelihood that the proponents supported Proposition 8 because they fear and dislike homosexuals).

138. Perry v. Schwarzenegger, 704 F. Supp. 2d 921, 1000-01 (N.D. Cal. 2010) (citing Romer v. Evans, 517 U.S. 620, 633 (1996)); U.S. Dep't of Agric. v. Moreno, 413 U.S. 528, 534 (1973); Palmore v. Sidoti, 466 U.S. 429, 433 (1984).

139. Perry v. Schwarzenegger, 704 F. Supp. 2d 921, 988 (N.D. Cal. 2010) (quoting a proponent of Proposition 8 for demonstrative purposes to show that much of the evidence presented in campaigning and defending Proposition 8 at trial was merely opinion and not fact). The proponents of Proposition 8 presented one witness to prove their twenty-three arguments. Id. at 931 . In the end, the witness identified only one difference between same-sex and heterosexual couples-some heterosexuals are able to create biological offspring. Id. at 932.

140. Id. at 1003 (citing the court's holding that Proposition 8 unconstitutionally infringes on an individual's right to due process and equal protection under the law). 


\section{The Trial Court's Denial of the Stay}

Following the trial court's decision on the merits, the defendant-intervenors moved to stay the judgment, ${ }^{141}$ and the trial court denied the motion. ${ }^{142}$ It noted that a stay is not granted as a matter of right, and that to be entitled to a stay, it must consider the following factors:

(1) whether proponents have made a strong showing that they are likely to succeed on the merits;

(2) whether proponents will be irreparably injured absent a stay;

(3) whether the stay will substantially injure other interested parties; and

(4) whether the stay is in the public interest. ${ }^{143}$

Regarding the first element, the trial court concluded that defendantintervenors were unlikely to succeed on the merits for two reasons. It noted that they probably lacked standing to appeal the case, as they have no authority to enforce Proposition 8 and because they presented little to no credible evidence at trial. ${ }^{144}$ Under the court's reasoning, only the

141. Order Perry v. Schwarzenegger, No. 3:09-cv-02292-VRW, 2010 WL 3025614 (Aug. 12, 2010), at 2; see Order Denying Defendant-Intervenors' Motion to Stay Pending Appeal at 2, Perry v. Schwarzenegger, 704 F. Supp. 2d 921 (N.D. Cal. 2010) (No. C 09-2292 VRW), available at https://ecf.cand.uscourts.gov/cand/09cv2292/files/Final_stay_order.pdf (indicating that defendant-intervenors are the only parties requesting a stay from enjoining Proposition 8).

142. Order Denying Defendant-Intervenors' Motion to Stay Pending Appeal at 6, Perry v. Schwarzenegger, 704 F. Supp. 2d 921 (N.D. Cal. 2010) (No. C 09-2292 VRW), available at https://ecf.cand.uscourts.gov/cand/09cv2292/files/Final_stay_order.pdf (finding that defendant-intervenors were unable to meet any of the factors necessary to justify a stay). Neither Governor Schwarzenegger nor the Attorney General Brown supported a stay and both separately filed opposition memoranda in response to defendants' motion for a stay, "respectfully" urging its denial. The Administration's Opposition to DefendantIntervenors' Motion for Stay Pending Appeal at 1, Perry v. Schwarzenegger, 704 F. Supp. 2d 921 (N.D. Cal. 2010) (No. 09-CV-02292 VRW), 2010 WL 3065300; Attorney General's Opposition to Defendant-Intervenors' Motion for Stay Pending Appeal at 2, Perry v. Schwarzenegger, 704 F. Supp. 2d 921 (N.D. Cal. 2010) (No. 09-CV-02292 VRW).

143. Order Denying Defendant-Intervenors' Motion to Stay Pending Appeal at 6 , Perry v. Schwarzenegger, 704 F. Supp. 2d 921 (N.D. Cal. 2010) (No. C 09-2292 VRW), available at https://ecf.cand.uscourts.gov/cand/09cv2292/files/Final_stay_order.pdf (quoting Virginian Ry. Co. v. United States, 272 U.S. 658, 672 (1926)) (emphasizing the difficulty of successfully moving for a stay "even if irreparable injury might otherwise result" because the decision is still left to the trial court's sound discretion).

144. Id. (diluting the strength of the legal arguments put forth by proponents at trial by showing deficiencies in their arguments and evidence on critical threshold issues); see also Michael J. Ritter, Note, Standing in the Way of Animal Welfare: A Reconsideration of the Zone-of.Interest "Gloss" on the Administrative Procedures Act, 29 REv. LiTiG. 951, 964 (2010) (outlining the modern requirements for Article III standing as including an (1) an injury in fact, which invades a legally protected right, and is concrete, particularized and actual or imminent; (2) causation; and (3) redressibility). The scope of Article III standing 
official defendants in Perry have Article III standing to pursue an appeal. ${ }^{145}$ The court decided the second factor against the defendant-intervenors because they failed to show that they, themselves, would be irreparably injured by a denial of the stay. ${ }^{146}$

After noting that the first two factors were the "most critical," the court explained that its previous analysis was sufficient to deny the stay, but proceeded to address the remaining two factors. ${ }^{147}$ The court determined that based on the evidence at trial, the only parties the court thought might be harmed would be the same-sex couples who were unable to marry because of Proposition $8 .^{148}$ With regard to the fourth factor, the court rejected the defendant-intervenors' contention that a denial of a stay would harm the public interest because California voters decided to enact Proposition $8 .{ }^{149}$ It concluded that the evidence at trial

has evolved over the last 80 years as the Supreme Court abandoned the limited "Case" and "Controversy" language and "abandoned the legal right test." Id. at 963. The newest iteration of Article III standing, as numerated above, was set forth by Justice Scalia in Lujan v. Defenders of Wildlife. Lujan v. Defenders of Wildlife, 504 U.S. 555, 560-61 (1992); Michael J. Ritter, Note, Standing in the Way of Animal Welfare: A Reconsideration of the Zone-of-Interest "Gloss" on the Administrative Procedures Act, 29 Rev. LiTIG. 951, 964 (2010). Even with the changes to the Article III doctrine individuals seeking standing still need to overcome the zone-of-interest test. Michael J. Ritter, Note, Standing in the Way of Animal Welfare: A Reconsideration of the Zone-of-Interest "Gloss" on the Administrative Procedures Act, 29 Rev. LiTIG. 951, 952 (2010). The zone-of-interest test is a self-imposed judicial development that seeks to balance the ability of individuals to seek redress for harm suffered with executive branch actions. Id. at 969.

145. Order Denying Defendant-Intervenors' Motion to Stay Pending Appeal at 5, Perry v. Schwarzenegger, 704 F. Supp. 2d 921 (N.D. Cal. 2010) (No. C 09-2292 VRW).

146. Id. at 7 (noting that the proponents "do not identify a harm to them that would result from denial of their motion to stay"). The proponents argued that the state will be harmed if a stay is not granted, as harm is the natural consequence that flows from enjoining an enactment of the people. Id. Furthermore, they argued that any marriage occurring after judgment yet before the appeal is decided will be subject to "a cloud of uncertainty." Id. Both of these arguments by the proponents failed, as they are: (1) not the state, (2) are not themselves attempting to wed someone of the same sex, and (3) already admit that the harms they discern only apply to "affected couples and ... the State." Id.

147. Id. at 8 (analyzing the last two factors despite already determining the stay will be denied).

148. Id. at 8-9 (accepting the argument by plaintiffs that harm would result from a stay and that it would hinder their access to relief).

149. Id. at 10 (refuting proponents' argument that the public interest would be damaged if a stay were denied, as there would still be confusion for marriages, before the constitutionality of Proposition 8 is determined). Although, the proponents believe that because Proposition 8 received a majority of votes the public interest would be damaged if a stay is denied. Id. 
showed that the implementation of Proposition 8 actually harmed the State of California. ${ }^{150}$

The defendant-intervenors challenged the trial court's decision on the stay to the Ninth Circuit, which scheduled oral argument for the case for December 2010. ${ }^{151}$ On its own motion, the Ninth Circuit panel expedited the case. ${ }^{152}$ Without explanation, the panel granted the defendant-intervenors' motion to stay the trial court's denial of the stay until the Ninth Circuit decided the issue. ${ }^{153}$ The Ninth Circuit's order requested that the parties brief both the merits of the case, as well as the Article III standing issue discussed by the trial court's order denying the stay. ${ }^{154}$

\section{PerRy's Possibilities}

At the outset of Perry, many expected the case to be appealed to and decided by the Supreme Court of the United States. ${ }^{155}$ Given the civil

150. Order Denying Defendant-Intervenors' Motion to Stay Pending Appeal at 10 , Perry v. Schwarzenegger, 704 F. Supp. 2d 921 (N.D. Cal. 2010) (No. C 09-2292 VRW) (finding that denying a stay would harm California).

151. Cynthia Laird, Uncertainty for Prop 8 Ballot repeal, B^y Are^ Rep., Aug. 19, 2010, http://www.ebar.com/news/article.php?sec=news\&article $=4998$ (confirming oral arguments will be heard by the Ninth Circuit in the first part of December 2010).

152. Order at 2, Perry v. Schwarzenegger, No. 3:09-cv-02292-VRW (9th Cir. Aug. 17, 2010) available at http://www.ca9.uscourts.gov/datastore/general/2010/08/17/10-16751_order.pdf (establishing accelerated briefing dates for both parties). Proponents of Proposition 8 requested a stay until their case could be heard on appeal. See Order at 2 Perry v. Schwarzenegger, No. 3:09-cv-02292-VRW (9th Cir. Aug. 16, 2010), available at http://www. ca9.uscourts.gov/datastore/general/2010/08/16/order_motion_stay.pdf.

153. Order at 2, Perry v. Schwarzenegger, No. 3:09-cv-02292-VRW (9th Cir. Aug. 16, 2010), available at http://www.ca9.uscourts.gov/datastore/general/2010/08/16/order_motion _stay.pdf. (granting appellant's motion to stay Chief Judge Walker's order enjoining enforcement of Proposition 8). The decision by the Ninth Circuit temporarily vacated the district court's decision to deny defendants' stay. See id.; Order at 2, Perry v. Schwarzenegger, 704 F. Supp. 2d 921 (No. C 09-2292 VRW), available at https://ecf.cand.uscourts.gov/ cand/09cv2292/files/Final_stay_order.pdf (denying the defendants' motion for stay in the trial court).

154. Order at 2, Perry v. Schwarzenegger, No. 3:09-cv-02292-VRW (9th Cir. Aug. 16, 2010), available at http://www.ca9.uscourts.gov/datastore/general/2010/08/16/order_motion _stay.pdf.

155. See Carlos Santoscoy, Gay Groups Not Welcome in Federal Marriage Suit, ON Top MAG., Aug. 8, 2009, http://www.ontopmag.com/article.aspx?id=4349\&MediaType=1\& Category=26 (mentioning the possibility of gay rights groups intervening in the Perry case due to the momentum of the case); David Cole, How Will Gay Marriage Fare in the Supreme Court?, N.Y. Rev. of Books Blog (Aug. 11, 2010, 10:10 AM), http://www.nybooks. com/blogs/nyrblog/2010/aug/1 1/how-will-gay-marriage-fare-supreme-court (discussing factors indicative of a Supreme Court decision on same-sex marriage); Jesse McKinley, Another Round in Same-Sex Marriage Case, N.Y. Timis, Aug. 15, 2010, http://www.nytimes. com/2010/08/16/us/politics/16prop.html; Lanae Erickson \& Jon Cowan, Moving the Middle on Marriage, Pol.tico.com, (Aug. 19, 2010, 4:51 AM), http://www.politico.com/news/sto- 
rights goals of the plaintiffs, the religious and moral tenets of the only participating defendants, the nature of the relief that the plaintiffs seek, and the representation of the plaintiffs by Boies and Olson, ${ }^{156}$ both sides were rightfully expected to seek a final resolution of the decision by the court of last resort in the United States. ${ }^{157}$ However, given the current status of the case, concern has shifted from the Supreme Court's determination of the merits of the case to the Supreme Court's determination of the standing issue. At most, any conclusions about Perry's probable future would likely be based on conjecture as to the parties' litigation strategies and the likely voting of the Justices of the U.S. Supreme Court. Instead of speculating about Perry's probable fate, this Part concludes the Article with a discussion of the possibilities for Perry, and the impact of those possible outcomes on the parties of the case.

\section{A. Standing}

Prior to considering the merits of the case, the Ninth Circuit, and possibly the Supreme Court, might resolve whether Chief Judge Walker erred in denying the defendant-intervenors' request for the stay by holding that the defendant-intervenors lack standing to appeal the trial court's judgment. In doing so, the Ninth Circuit, which is expected to release its deci-

ries/0810/41214.html (asserting that the Supreme Court will eventually have to decide whether to uphold or reverse the District Court's decision on Proposition 8); Maura Dolan, Prop. 8 Trial to Include Unprecedented Testimony, L.A. Times (Jan. 11, 2010), http://articles.latimes.com/2010/jan/11/local/la-me-prop8-trial11-2010jan11 (noting that from the beginning of the trial, commentators and the parties themselves expected the case to reach the Supreme Court in the fall of 2011).

156. John W. Dean, The Olson/Boies Challenge to California's Proposition 8: A HighRisk Effort, FindLaw (May 29, 2009), http://writ.news.findlaw.com/dean/20090529.html (discussing Boies and Olson, including their previous history working together and their ultimate plans for disposition of their Proposition 8 challenge).

157. See Jesse McKinley, Another Round in Same-Sex Marriage Case, N.Y. Times, Aug. 15, 2010, http://www.nytimes.com/2010/08/16/us/politics/16prop.html (suggesting the circumstances surrounding resolution of Proposition 8 may be favorable for Supreme Court review); Lanae Erickson \& Jon Cowan, Moving the Middle on Marriage, Pourt. ICO.COM, (Aug. 19, 2010, 4:51 AM), http://www.politico.com/news/stories/0810/41214.html; see, e.g., Maura Dolan, L.A. County Registrar's Office in Norwalk to Stay Open Late Wednesday for Gay Marriages, L.A. TIMEs, Aug. 16, 2010, http://latimesblogs.latimes.com/ lanow/prop_8; David Cole, How Will Gay Marriage Fare in the Supreme Court?, N.Y. Rev. OF Books Blog (Aug. 11, 2010, 10:10 AM), http://www.nybooks.com/blogs/nyrblog/2010/ aug/11/how-will-gay-marriage-fare-supreme-court. 
sion toward the beginning of $2011,{ }^{158}$ might thereby avoid addressing the merits of the case. ${ }^{159}$

Either way the Ninth Circuit panel decides, the losing party could appeal the decision to the Supreme Court. ${ }^{160}$ Like the Ninth Circuit, the Supreme Court may dodge the issues presented at trial by deciding that the defendants probably lack standing to appeal. ${ }^{161}$ If either the Ninth Circuit or the Supreme Court held that the parties lacked standing, those decisions could spell an end to Perry. The Ninth Circuit certified a question regarding the defendant-intervenors' standing under State law, stating that the outcome will depend on whether California law affords them a sufficient state-recognized interest to form the basis of its injury in fact to satisfy Article III. ${ }^{162}$

\section{B. The Merits}

Because the defendants have filed a Notice of Appeal, the Ninth Circuit will consider the appeal and issue a decision, ${ }^{163}$ which could officially dispose of the case on standing grounds, as previously discussed, or reach the merits. In reviewing the decision of the trial court, the Ninth Circuit would review Chief Judge Walker's findings of facts under an abuse of discretion standard, and would conduct a de novo review of his conclusions of law. ${ }^{164}$

158. Court Halts Calif. Gay Marriages Pending Appeal, Associnted Press (Aug. 17, 2010, 2:06 AM), http://www.msnbc.msn.com/id/38730337/ns/us_news-life (reporting on the Ninth Circuit's decision to stay Chief Judge Walker's order allowing same-sex marriage licenses to be issued before the defendant-intervenors appeal).

159. Whether the Ninth Circuit or Supreme Court will determine that the standing issue precludes the defendant-intervenors from appealing the merits is unclear. It is not even clear that the defendant-intervenors have standing to appeal the trial court's order as to the stay. Cf. Salazar v. Buono, $130 \mathrm{~S}$. Ct. 1803, 1814 (2010) (holding an appellant had standing to appeal a judgment in his favor). The Court noted that a party has a "judicially cognizable" interest in assuring that a judgment in his favor is enforced. Id. at 1814-15. As noted in the majority opinion, "[h]aving obtained a final judgment granting relief on his claims, Buono had standing to seek its vindication." Id. at 1815.

160. 28 U.S.C. $\$ 1254(1)$ (2006) (explaining the available methods of appeal to the Supreme Court of the United States).

161. Id.

162. Perry v. Schwarzenegger, 628 F.3d 1191, 1196 (9th Cir. 2011), certified question accepted (Feb. 16, 2011).

163. See 28 U.S.C. $\$ 1295$ (a)(1) (2006) (conferring jurisdiction to the Ninth Circuit when appealing a final decision from the district court); see generally Notice of Appeal, Perry v. Schwarzenegger, 704 F. Supp. 2d 921 (N.D. Cal. 2010) (No. 09-CV-2292 VRW) (recognizing that the case continues to move through the appellate process and has yet to reach a final conclusion).

164. See Long Beach Area Peace Network v. Long Beach, 574 F.3d 1011, 1019 (9th Cir. 2009). 
To reverse in favor of the proponents of Proposition 8 on the merits, the Ninth Circuit would have to disagree with the trial court on all of its Due Process Clause and Equal Protection Clause holdings. At this phase, the Perry plaintiffs could decide to seek review of the case by the Supreme Court or to not pursue such review. A decision that disfavors the plaintiffs on both the Equal Protection and Due Process grounds would leave intact Due Process and Equal Protection precedent that could possibly hinder future litigation efforts of gays and lesbians under these constitutional provisions in the Ninth Circuit, as well as other courts persuaded by the opinion. However, a review and reversal of the trial court by the Supreme Court would create even more detrimental precedent that would be binding on all circuit courts of appeals.

Alternatively, to affirm in favor of the plaintiffs, the Ninth Circuit would need to agree with the trial court's decision as to only one of the grounds for its decision, whether it is Due Process or Equal Protection. Such an outcome would leave the defendants with the decision of whether to seek or not seek review from the Supreme Court. It is still within the realm of possibility that the defendant-intervenors would not seek Supreme Court review of an unfavorable Ninth Circuit decision, quite possibly to prevent an impactful Supreme Court opinion adverse to the religious right's interest.

If the party losing on appeal to the Ninth Circuit sought review by the Supreme Court, the Supreme Court could decide to either grant or deny the party's petition for writ of certiorari. ${ }^{165} \mathrm{~A}$ denial of the petition would permit the Ninth Circuit decision-whether in favor of the plaintiffs or defendant-intervenors - to stand, and the losing side would have no recourse. Commentators have speculated whether the Supreme Court would even grant certiorari to hear Perry given the novelty of gay marriage, and many have guessed which justices would favor, and which justices would disfavor, hearing the case. ${ }^{166}$ However, the relatively recent confirmations of Justice Sonya Sotomayor and Justice Elena Kagan cast more doubt on these speculations. But because the Court needs only a vote of four justices to grant certiorari, either outcome is, of course, possible. $^{167}$

165. See Rutherford v. Am. Med. Ass'n, 379 F.2d 641, 645 (7th Cir. 1967) (noting that the Supreme Court's review of decisions of the circuit courts of appeals is discretionary). The court noted that such review is not a matter of right. Id.; 28 U.S.C. $\$ 1254(1)$ (2006).

166. David Cole, How Will Gay Marriage Fare in the Supreme Court?, N.Y. REv. OF Books Blog (Aug. 11, 2010, 10:10 AM), http://www.nybooks.com/blogs/nyrblog/2010/aug/ 11/how-will-gay-marriage-fare-supreme-court (theorizing that the Supreme Court is very nearly split on the constitutionality of Proposition 8).

167. Poster Exch., Inc. v. Nat'l Screen Serv. Corp., 362 F.2d 571, 574 (5th Cir. 1966) (quoting Daniels v. Allen, 344 U.S. 443, 492 (1953)) (discussing denial of certiorari gener- 
If the Supreme Court decided to grant the petition to hear the case, it would then issue an opinion on the case. In addition to the amicus curiae briefs the Court would review, the Court's broad discretion would leave more potential variations as to a substantive ruling by the Supreme Court than might be possible at the Ninth Circuit. Certainly though, a Supreme Court decision would either finally dispose of the case by holding that the defendants lack standing, leave Proposition 8 unenforceable under the trial court's order and lift any stay, or permit California officials to continue to deny marriage licenses to same-sex couples.

A reversal of the trial court decision would have disastrous consequences for the lesbian and gay rights movement, particularly with regard to making societal advances through constitutional litigation strategies. Such negative precedent from the Supreme Court would make Perry the first case since Bowers v. Hardwick ${ }^{168}$ to fail to offer legal parity to homosexuals in the same manner as heterosexuals under the Constitution; the decision might even reverse the gains made in Lawrence $v$. Texas ${ }^{169}$ and Romer v. Evans. ${ }^{170}$

An affirmation by the Supreme Court would potentially be a huge victory for the gay and lesbian rights movement, offering additional positive precedent to advance its goals. The Court might hedge against this victory by limiting its decision to the unique situation of California and the context in which Proposition 8 passed. Several of Chief Judge Walker's holdings regarding the defendant-intervenors' purported legitimate government interests relied on the unique laws of California, some with regard to the parallel institution of domestic partnerships, the eighteen thousand valid same-sex marriages, and same-sex adoption. ${ }^{171}$ The rationale for the rejection of these interests simply might not apply in other states that do not recognize domestic partnerships for same-sex couples or the right of same-sex couples to adopt. ${ }^{172}$ These holdings as to the lack

ally). The Supreme Court has previously noted that the denial of certiorari is often undisclosed. Brown v. Allen, 344 U.S. 443, 492 (1953). Denial may be based on reasons that are unrelated to the merits of the case. Id.

168. Bowers v. Hardwick, 478 U.S. 186, 191 (1986), overruled by Lawrence v. Texas, 539 U.S. 558 (2003) (upholding a Georgia statute that criminalized sodomy even in the privacy of one's home).

169. Lawrence v. Texas, 539 U.S. 558 (2003).

170. Romer v. Evans, 517 U.S. 620, 633 (1996); see Christian Legal Soc'y v. Martinez, 130 S. Ct. 2971, 2978 (2010) (upholding the Hastings College of Law non-discrimination policy for student organizations).

171. Perry v. Schwarzenegger, 704 F. Supp. 2d 921, 997-1002 (N.D. Cal. 2010) (discussing proponents' failure in providing sufficient evidence to advance each of their six purported government interests).

172. See, e.g., Michael J. Ritter, Note, Adoption by Same-Sex Couples: Public Policy Issues in Texas Law \& Practice, 15 TEx. J. C.L. \& C.R. 235, 235 (2010) (explaining that 
of a rational basis for Proposition 8 underpin to a substantial degree the trial court's conclusions as to both the Due Process Clause and Equal Protection Clause. ${ }^{173}$

Finally, even if the Supreme Court affirmed the trial court's decision, Perry's story may not end there. As the history of Proposition 8 demonstrates, judicial victories on constitutional grounds are not immune from constitutional amendment. ${ }^{174}$ Though discussions about passing an amendment to the federal constitution to prohibit same-sex marriage have dwindled since President George W. Bush's reelection campaign in $2004,{ }^{175}$ a decision by the Supreme Court in favor of gay marriage might revitalize public efforts for an amendment to overturn the decision. The passage of Proposition 8 in the state most protective of the rights of gays and lesbians ${ }^{176}$ indicates that a serious push for such an amendment would not be surprising.

The future of Perry is uncertain at best. The various possibilities of decisions by any of the parties on either side regarding the pursuit of appeal, or decisions by the Ninth Circuit and the Supreme Court on the procedural aspects or merits of the case, cast suspicion on any prediction about Perry's fate. The long road leading up to Perry might end in the Ninth Circuit; it might result in the biggest win for gays and lesbians in the U.S. Supreme Court since Lawrence; or it may even result in a constitutional amendment overturning a Supreme Court decision affirming the trial court and thus reversing relatively recent gains by the gay and lesbian movement. But, of the multiplicity of possibilities, and despite its

Texas adoption statutes are ambiguous as to whether same-sex couples may adopt children). Currently, ten states and the District of Columbia have explicit statutes sanctioning the adoption of a child by a same-sex couples. Id. at 240 . Additionally, at least eighteen additional states provide some avenue for adoption by same-sex couples and four states explicitly bar same-sex couples from entering into adoptions. Id.

173. Perry v. Schwarzenegger, 704 F. Supp. 2d 921, 991-99 (N.D. Cal. August 4, 2010).

174. For a complete discussion of gay marriage in California, refer to Section II of this Article.

175. Mike Allen \& Alan Cooperman, Bush Backs Amendment Banning Gay Marriage, Wash. Post, Feb. 25, 2004, http://www.washingtonpost.com/wp-dyn/content/article/ 2004/02/25/AR2005032201695_pf.html (referring to the comments made by President Bush in regard to ensuring marriage be reserved to a man and a woman by permanently changing the Constitution to reflect that idea).

176. See Veronique de Turenne, California-The Most Gay-Friendly State in the Union, L.A. Times Blog (Oct. 9, 2008, 9:03 AM), http://latimesblogs.latimes.com/lanow/ 2008/10/california_- t.html; see also Laws, HRC_CALIFORNIA, http://www.hrc.org/your_ community/california/california_laws.htm (last visited Dec. 26, 2010) (detailing the various laws in California protecting LGBT people and their families from discrimination). 
ultimate fate, Perry will likely live up to commentators' description as the most-watched civil rights case of this decade. ${ }^{177}$

177. See, e.g., Ted Olson Supports Carly Fiorina's Senate Bid. Carly Fiorina Supports Prop 8. Huh!, QueErTy.com (Aug. 4, 2010), http://www.queerty.com/ted-olson-supportscarly-fiorinas-senate-bid-carly-fiorina-supports-prop-8-huh-20100804. 
